\title{
The world we're in: Social work now and then
}

\author{
Mike O’Brien
}

Associate Professor Mike O'Brien works at the School of Counselling, Human Services and Social Work, Auckland University.

\section{Abstract}

The last half century has witnessed significant changes in the highly influential social and economic world in which the practice of social work happens. This paper explores the beginning, middle and end points over that time - 1965-6, 1988, 2013 - identifying the major areas of social, cultural and economic focus in each of these years and examines implications for the delivery of social services and the practice of social work. Drawing on a sample of media focus and presentations for each of the three years (as reflected in a newspaper at the time), the article identifies principal areas of social, cultural and economic interest and attention in each area. It then uses that data to inform a discussion of the ways in which those areas shaped (or failed to shape) social work practice and social services delivery at the time. Drawing on those reflections, the article concludes with a discussion of the ways in which the worlds of clients and practitioners shape social services delivery and organisation and the practice of social work. It concludes with brief reflections on what this might mean for the directions of social work practice.

\section{Introduction and background}

Social work practice and social work literature regularly emphasise the significance of 'context' in shaping both the lives of the individuals, families and communities that practitioners work with and the nature and scope (in the widest senses of those two words) of practice itself. But, what does this mean and is it a statement of intent or of action, or perhaps of orientation? The interest here is in exploring this, and related, questions in the light of the Association's half century, through examination of how the social work journal (in its different titles) has reflected (or not) contemporary issues and debates in a sample of journals over that half century.

There is, of course, an important assumption here, namely that the journal contributions will reflect the wider environment (context) within which social work occurs. The parameters and implications of this assumption are beyond the discussion here, except to say that if the journal is about social work practice in Aotearoa (in the widest senses of that term) (and, arguably it is), then it is reasonable to expect that those articles will reflect, in part at least, dimensions of that wider context. Context is, then, being taken in a wide sense here rather than in the narrower sense of the immediate context of the life of the individual or family, although the two may of course be linked as, for example, might occur in a situation of redundancy. 
Given the 50-year timeframe we are working with for this special edition of the journal, for reasons of manageability, it was decided to take three reference points for exploration, namely the year of the Association's early journals (1965-6) ${ }^{1}$, the latest year for which journals are available (2013) and the mid-point (1989). All the major articles for the journals of those three years were reviewed, both the titles of the articles themselves and their more detailed contents. In addition, significant other material in the journals, such as report reviews (but not book reviews), were included in order to give a more comprehensive coverage. The focus was on the topics of the articles and other relevant material, not on a detailed examination of the issues and arguments within those articles. The journal has had various titles over its 50-year history; to avoid confusion within this text I will simply use the current name (Aotearoa New Zealand Social Work (ANZSW). I should note too that I am the author of one article in the 2013 volume. In the interests of conserving space, I have attached the table of contents for each of the volumes as an appendix to this article (unless quoting directly from the text within a particular article), rather than fully referencing every article within the text. ${ }^{2}$

The journal articles were then placed against and alongside current issues of interest and attention in the media for each of the three years by examining coverage in the New Zealand Herald for each of the chosen years. ${ }^{3}$ This paper was chosen because it is published in the largest population centre and is a more readily accessible and available source than other media. Material was included either because it was considered to be of national significance and interest (international material was omitted from consideration as I was focusing on the New Zealand experiences) or because, based on knowledge of social work and the social services, it covered a topic of, potentially, general direct or indirect interest to social work and the social services. ${ }^{4}$ Substantive stories and editorials were both included. As with the journal articles, the focus was the topic itself, not the substantive arguments or approach to that topic.

Why, then, go to the media? While acknowledging the limitations and selectiveness which are part of the media, they do provide a historical record of what was regarded as important at a particular time. It is a record which is more reliable than, for example, relying on human memory to describe events of 50 and 25 years ago. This is not an argument that the media are 'neutral' and 'objective' in whatever ways those terms might be used, but is simply an assertion that they provide a publically available record which identifies events, activities and emphases at a point in time. It is certainly possible that some significant events and activities were not presented, but the number of these is likely to be small. These issues were identified on the basis that they were part of the political and economic context and likely to be of significance for the social services, client communities and / or social work practice.

1 The first journal was published in August 1965, and early editions contained a mixture of articles and internal Association news. The current article has not focused on the Association's news material. In the first year two editions appeared, with four the following year; hence the use of material from both 1965 and 1966.

2 Because the Association news material in the early editions of the Journal is not included in the coverage of this article, the appendix only includes the substantive articles and reports.

3 Initially it had been intended to include the Dominion/Dominion Post in the coverage, but initial work indicated that this did not add anything to the list of material identified and it was therefore decided to limit coverage to the Herald. Coverage was limited to a close examination of each Wednesday of the particular year, earlier comprehensive daily review failing to add to the topics identified.

4 Thus, stories of personal tragedy and triumph were omitted. 


\section{Context and social work}

The emphasis on 'context' and environment in social work requires little comment because it is so universal, reflected in such widely used phrases as 'the person and / in the environment' or, for example, in the title of the widely used social work text, Social work. Contexts and practice (Connolly and Harms, 2013). In the third edition of this text, Williams (2013, v) comments in the Foreword, '...if there is one truism of social work it is that it is context bound, situated and shaped by the socio-economic, political and cultural milieu in which it operates'. There are, she suggests, three dimensions to that context - socio-political, geographical and social work's knowledge and value base (op. cit.). The emphasis here is on the first of these dimensions, but I will suggest later that the journals also give some priority to the last of the three, the knowledge and value base.

Space precludes a comprehensive discussion of the diverse approaches to 'context' in the social work literature. Suffice to say that a range of introductory social work texts all note its significance in different ways as is reflected in this sample of the literature. Interestingly, Worsley, et al. (2013) in their discussion of key social work concepts do not include 'context' as one of their key concepts. This omission, however, is not the pattern of social work texts. Higham (2006), for example, talks of the social policy context encompassing such areas as welfare traditions, social policy, cultural influences, organisational and international dimensions while Jones $(2009$, p. 41) uses the term 'context' to refer to written text in her discussion of the development of critical reading among students. In a similar wide ranging coverage, Adams, Dominelli, \& Payne (2002) divide their text into three parts, the first of which is entitled 'Social work in context', with a series of chapters traversing, inter alia, organisational, political, ethical, legal, professional and research components. Similarly, Thompson (2009) devotes chapter two to what he calls 'the legal and political context', and its importance in shaping social work.

Dominelli (2004) uses the term with a number of meanings, but gives particular emphasis to the impact of international and global considerations (especially neoliberalism and new managerialism) on practice. Her work includes a chapter entitled 'A profession in changing contexts'. In a related vein, Cox and Pawar (2013) devote a chapter of their book on international social work to a discussion of the global context which shapes and informs that work. That chapter incorporates coverage of global social problems, the organisational and ideological context and what they describe as, 'the emerging political context' (op. cit., p. 97).

Fook (2002, p. 142) describes social work as 'contextual practice', going on to set out five dimensions - the nature of context, positionality, working within whole contexts, practice and knowledge that is transferable across different contexts and reframing skills in contextual terms (op. cit., p. 142-3). This practice approach to the notion of context is also reflected by Kirst-Ashman (2010). She incorporates a discussion of contexts in her review of the competencies required of social workers, highlighting the ways in which these contexts shape practice and the requirement for practitioners to act on these contextual influences.

Payne's (2005) discussion refers to 'contextual practice' to describe social work activities aimed at effecting change in what he calls 'the wider social systems and within the present social order'. Interestingly, he notes that contextualisation, '....involves focusing on clients' own understanding of their 'social being' rather than workers' assumptions or policies' 
(Payne, 2005, p. 306). He is, then, linking both the direct practice dimensions of context and the breadth of influences on that practice.

In a broad sense, then, 'context', as discussed in the literature, has a number of elements; organisational, political and practice dimensions are three of the key features. With this background in mind, what is the relationship between the journals and key issues of the time, as reflected in the media coverage? The next section summarises the journal articles and media focus for each of the periods under review. The article then concludes with reflections on the relationship between the two and the implications for practice.

\section{The journals and the media}

\section{$1965-1966^{5}$}

The journal

The Association's initial journals incorporated both substantial articles and short pieces focused on the business of the newly developing Association; the Journal was the Association's only publication at the time. The initial edition contained two articles on children, two articles on the role of social work and a report on a rehabilitation conference. The following edition also carried two articles on children and commentaries on social work education and on social workers and legislation. It included the programme for the 1966 Conference, the theme of which was 'a critique of the welfare state' with plenary sessions on the professions in the welfare state and on the welfare state and the voluntary spirit. Five groups were identified for the conference - health services and the welfare state, migration in the welfare state, children and adolescents, compassion in the welfare state and poverty in the welfare state. The second edition in 1966 carried many of the papers from that conference (reflected in the contents list in the appendix) and, continuing the emphasis on children, a paper on adoption. Migration, youth services, social change, ageing, institutional programmes for delinquent youth, suicide prevention and children with personality problems formed the substance of the third edition, while the final edition for that year again included two articles related to children, an article on disability and two reports from the IFSW conference in Washington.

\section{The media}

Unlike 1989, the 1965-66 period does not have a strong recurrent theme, media commentary being quite diverse. The war in Vietnam was certainly a strong area of focus, but the review of the media coverage revealed a heterogeneous mixture of issues. Interestingly, economic matters received only limited attention, while medical benefits, social security adequacy, a mixture of issues affecting children and children's wellbeing, educational topics (including access and school leaving age) and a range of issues around racial equality (including sports tours to South Africa, educational outcomes and housing discrimination) were all given attention on different occasions over this period.

\section{8-89}

The journal

The December 1988 edition carried articles on white racism, sexual abuse and social work education, while the reports in that edition focused on a report on birth mothers and another

5 Because the first journal appeared in August 1965, the first two volumes (incorporating six editions) is covered in this overview. 
report on child sexual abuse. The next two editions (which appeared together) carried two articles on women in social work, one on community development and a fourth article on a therapeutic community. It also included two brief notes on supervision issues, a report on a social work union and on an adoption report. The first edition of volume two contained articles on public health, the Australian labour market and a general article on what was called 'social work today' in which the author took up issues arising from the developing contractual environment and biculturalism. The final edition in 1989 encompassed articles on contracting out, community service in probation, accountability and social work staff meetings. This edition also contained a brief report on a social audit.

\section{The media}

Media comments and commentary throughout this year were focused strongly on the issues associated with the ongoing implementation of the neoliberal agenda which had been introduced in the previous years (Kelsey, 1997) Thus, the newspapers carried stories about asset sales, shopping hour changes, changes in employment and unemployment, job losses and the drivers and effects of the economic and social changes that were proposed or had been undertaken already, including health and school reforms and amendments to the liquor laws. Alongside these topics, there was some attention in the media to issues associated with land rights, Māori health and race relations, the Bill of Rights and pay equity. More specifically, issues of child abuse and the introduction of the Children Young Persons and Their Families Act, adoption, abortion, benefit costs and benefit changes received some, albeit limited, direct attention.

\section{3}

The journal

Volume one in 2013 included articles on a teen parent unit, rural social work, mental health services, family group conferences, community social work, support group for women with depression and the competency assessment portfolio. The next volume carried a series of articles on the Christchurch earthquakes, taking up (a) particular aspects directly related to services and practice such as relationships with companion animals, disaster emergency response, gendered violence, evacuees on haemodialysis, support for human service workers; (b) more general issues such as the effects on refugees, sustainable development, inner city issues, community wellbeing and (c) a personal reflection on the effects of the disaster. The final volume for the year moved in a totally different direction with a series of articles reflecting and commenting on the experiences and effects of the decade since the introduction of social work registration. Contributors to this volume focused on the impact of registration on such diverse areas as social work education, voluntary and health agencies, continuing professional development, registration debates and the social justice remit for social work, concluding with an interview with a former Association President.

\section{The media}

While broader issues such as the botulism scare, national security, the Pike River explosion, trade deals and asset sales featured in newspaper stories in 2013, there was also no shortage of more direct macro and micro issues related to social work and social services. As in 1989, Treaty considerations were an important focus, along with housing matters, abuse and violence (including the work on 'vulnerable' children), marriage equality, youth unemployment, welfare reform, child poverty and inequality. Issues arising from the Christchurch earthquakes, casino expansion and a range of health related matters (smoke free, 
obesity, prescription costs) were all taken up at some point during the year as were crime and education issues such as charter schools and Novopay.

\section{Reflections and implications}

To return then to the questions that shaped this article, namely how, if at all, has the context of social work practice (as reflected through the Association journals and the media material reviewed here) changed over the last half century and what might this mean for social work in Aotearoa. The first, self-evident, observation is that the context of and for the practice of social work has changed significantly over these 50 years. While the observation is in itself rather trite (after all, such change is to be expected), there are fundamental questions following from this observation: what is the nature of that change and what are its implications for social work in Aotearoa? It is this question that informs the basis for the discussion that follows.

Put simply, the sample of journals reviewed here reflects a shift from the broad context of practice to a focus on the more proximate and immediate events and activities that shape the context currently. Put slightly differently, by way of contrast with the wider lens reflected in the early journals, the contemporary approach to 'context' focuses on what frames the day-to-day activities and demands of undertaking practice. This is demonstrated in the way in which the 1965-66 volume addressed a range of issues around the broad contextual environment while the recent (2013) journals have focused on more immediate practice issues and given comparatively limited attention to these broad considerations and their influence on practice. ${ }^{6}$

Thus, for example, while there is significant attention to broad welfare issues in the 1960s, the 2013 journals do not take up such critical questions as housing affordability, welfare reforms, child poverty and child abuse, all of which feature in the media. Rather, the 2013 volume has a strong direct focus on the immediate context of practice. To illustrate this, with one exception, the volume on the Christchurch earthquakes focuses on the effects of the earthquakes on practice and practitioners rather than broader distributional and compensation issues arising from the earthquakes and the subsequent rebuilding of the city. Interestingly, the 1989 volume reflects something of a middle point, perhaps indicating a transition around the nature of context. In that year's volume, there is some indirect attention to elements of critical contextual influences such as the neoliberal changes (for example, the development of contracting) and their impact in such key areas as unemployment, but there is no substantial discussion of the impacts of the neoliberal programme. This volume did reflect elements of the significance of racism and of the Treaty of Waitangi and of Māori rights, both of which received some attention in the media during that year.

Readers will have noted too that the Journal's focus was wider than is reflected in the media issues in 1965-66. For example, there is an interest in broader welfare state issues and in children that is not apparent in the media focus in 1965-66. By way of contrast, as I have noted above, the position is largely reversed half a century later, reflected in the lack

6 This should not be construed as a criticism of any of the journal content or of its contributors; the purpose here is to explore wider questions, not to engage in a critique of, or commentary on, content. 
of attention to such critical issues as housing affordability, child abuse and child poverty in the 2013 journal, important media issues in the last year. This raises an important consideration for practice. If the media is not a good guide of the significant issues shaping the context of practice, how, then, does attention to those issues arise? It can only occur through sustained critical reflection on the totality of the context of practice, an issue to which I return below.

There is one other question to be addressed first, namely what, then, has shaped and influenced the change? The narrowing of the focus to the more immediate practice context reflects and is the result of the changes in the political economy within which social work is practised. Reflecting managerial and neoliberal influences over the last quarter of a century, the practice of social work is now narrower and more directly subject to closer organisational control and specification (Ferguson and Woodward, 2008; Garrett, 2009). This is demonstrated, for example, in the use of contracts between the state and social work agencies in which the emphasis is on meeting particular outputs and undertaking specified activities. Those contracts are decided by the state in terms of services it purchases through the contract specifications. Agency survival is dependent in many instances on meeting these outputs and renewing contracts. Social workers' employment is similarly dependent. Too often, the contractual requirements prevail over the needs and circumstances of families / communities and prevent practitioners from responding to those needs and circumstances fully and effectively.

Neoliberalism's exclusive focus on the small, residual state and on the 'freely acting individual' reinforces this emphasis and gives it political legitimacy. It is an emphasis which treats the individual as a 'free' agent exercising 'choice'. The economic and social context which influences, shapes and limits that choice is either denied or neglected (or both). As a direct and indirect result of neoliberal shaping, social work is pushed into and constrained towards paying attention to the individual qua individual. It is a push which means that the wider context within which individuals and families live their lives, struggle with daily demands and exercise choices is denied, forgotten, ignored and/or overlooked.

This change occurs in an intriguing contextual change, namely the growth and development of greater professionalism within social work. Notions of 'being professional' and 'acting professionally' are much stronger in 2013 (a volume of the journal is devoted to registration) than they were in 1965-66. There was only an emerging/embryonic professional Association in 1965 to stand against or alongside social work and social service agencies. Indeed, the very idea of 'being professional' was itself the subject of considerable debate. 'Professionalism' provides the basis of an identity and a direction that is independent of the employing agency, but in 2013 the narrower approach to the context of practice seems closer to the agency demands and requirements than it does to the exercise and expression of independent identity reflective of professional history, ethics and values.

What might this mean as social work in Aotearoa looks to the next half century and the place of context in practice over that time? Two points might be made, by way of concluding comments. First, if social work is to be true to the nature of context and the significance of context for practice, then we need to reflect on not just the immediate dimensions, but to extend that to the wider social and economic considerations that shape the lives, circumstances and opportunities of those with whom we work and the communities in which they 
live, an argument which is reflected in some (but not all) of the academic and professional literature discussed above. The context of those lives, circumstances and opportunities is vital to practice and our reflection on that practice needs to extend to that context and to the action we need to take resulting from that reflection.

Second, and in part associated with the preceding argument, the issues which capture the attention of the media will not necessarily be the issues which form the heart of the broad context of the individuals, whānau and communities we work in, with and for. In that sense, it can be argued, as I have suggested above, that the media focus does not do justice to the context of and for social work. It is at best an indicator or something of an incomplete bellwether. Indeed, as the preceding discussion suggests, social work was engaged with those broader issues more than the media in the first period under review. This, then, raises an important issue for social work and social work practice. If we cannot draw or rely on the media for identifying these important contextual questions, where, then do we turn?

I want to suggest that the most critical and substantive influence on attending to the totality of context has to be a strong critical reflection on the experiences informed by practice, a critical reflection that is informed by social work values and ethics and by constant attention to the goals and purpose of social work and an understanding of its historical roots. As has been the case historically, that critical reflection on the lives and experiences of users and communities will have to be informed by a strong and applied sense of social justice. Armed with this critical core of its history and ethics, this will then lead social work practice to a comprehensive and exciting use of context over the next 50 years, true to both the history and values of social work and to the totality of the world in which individuals, whānau and communities live.

\section{References}

Adams, R., Dominelli, L., \& Payne, M. (Eds), (2002). Social work. Themes, issues and critical debates (2nd ed.). Basingstoke: Palgrave.

Agbim, K., \& Ozanne, E. (2007). Social work educators in a changing higher education context: Looking back and looking forward 1982-2005. Australian Social Work, 60(1), 68-82.

Connolly, M., \& Harms, L. (2013). Social work. Contexts and practice (3rd ed.). Melbourne: Oxford University Press. Cox, D., \& Pawar, M. (2013). International social work. Issues, strategies, and programs (2nd ed.). Los Angeles: Sage.

Dominelli, L. (2004). Social work. Theory and practice for a changing profession. Cambridge: Polity.

Ferguson, I., \& Woodward, R. (2008). Reclaiming social work: Challenging neo-liberalism and promoting social justice. Los Angeles: Sage.

Fook, J. (2002). Social work. Critical theory and practice. London: Sage.

Garrett, P. (2009) Transforming children's services?: Social work, neoliberalism and the modern world. Maidenhead: Open University Press.

Higham, P. (2006). Social work. Introducing professional practice. London: Sage.

Jones, S. (2009). Critical learning for social work students. Exeter: Learning Matters.

Kelsey, J. (1997). The New Zealand experiment. A world model for structural adjustment (2nd ed.). Auckland: Auckland University Press / Bridget Williams Books.

Kirst-Ashman, K. (2010). Introduction to social work and social welfare. Critical Thinking Perspectives. Belmont: Brooks Cole.

Orme, J., \& Powell, J. (2008). Building research capacity in social work: Process and issues. British Journal of Social Work, 38(5), 988- 1008.

Payne, M. (2005). Modern social work theory (3rd ed.). Chicago: Lyceum Books.

Thompson, N. (2009). Understanding social work. Preparing for practice (3rd ed.). Basingstoke: Palgrave Macmillan.

Williams, C. (2013). Foreword. In M. Connolly \& L. Harms. Social work. Contexts and practice (pp. v-vi). Melbourne: Oxford University Press.

Worsley, A., Mann, T., Olsen, A., \& Mason-Whitehead, E. (Eds). (2013). Key concepts in social work practice. London: Sage. 
Appendix. Relevant journal contents.

AUGUST 1965, vol.1, no.1

\begin{tabular}{|c|c|c|}
\hline \multirow{3}{*}{ Report } & Helping Ill-Treated Children & $5-7$ \\
\hline & Group Counselling & $19-21$ \\
\hline & National Income and Social Welfare & $23-25$ \\
\hline Archdall, R. & Pan Pacific Rehabilitation Conference & $25-27$ \\
\hline \multicolumn{3}{|c|}{ Regional Conference } \\
\hline \multirow[t]{2}{*}{ report } & The Emotionally Disturbed Child & $31-33$ \\
\hline & Social Worker in New Zealand & $33-35$ \\
\hline Barnett, N. & The Role of the Social Worker Today & $35-43$ \\
\hline \multicolumn{3}{|c|}{ NOVEMBER 1965, vol.1, no.2 } \\
\hline Report & Community Development & $13-15$ \\
\hline Anderson, L. & Child Welfare in New Zealand & $15-23$ \\
\hline Greenhough, M. & Deprived Children & $41-43$ \\
\hline Wadsworth, E. & Training for Social Work & $45-47$ \\
\hline \multicolumn{3}{|c|}{ FEBRUARY 1966, vol.2, no.1 } \\
\hline Ford, C. & The Social Structure of the Institution & $5-9$ \\
\hline Report & The Role of the Social Worker in Community Planning & $15-16$ \\
\hline Report & The Urbanisation of the Maori & 25 \\
\hline Kendrick, J. & Growing up in Suburbia & $33-37$ \\
\hline Morrison, J. & Mothers who can't Cope & $39-40$ \\
\hline \multicolumn{3}{|c|}{ MAY 1966, vol.2, no.2 } \\
\hline Walsh, J. & Professions in the Welfare State & $11-21$ \\
\hline Downey. L. & Has the Welfare State Driven out the Voluntary Spirit? & $21-29$ \\
\hline \multirow[t]{2}{*}{ Kendrick, J. } & The Care of the Crippled, Handicapped and & \\
\hline & Disabled in the Welfare State & $33-45$ \\
\hline Halsall, R. & A Community Mental Health Programme? & $45-53$ \\
\hline Heads, M. & Poverty in the Welfare State & $55-63$ \\
\hline Bichan, R. & Secondary Poverty in the Welfare State & $63-69$ \\
\hline Collins, N. & Adoption & $71-79$ \\
\hline
\end{tabular}

AUGUST 1966, vol.2, no.3

Jones, P.

McCreary, J.

Morrison, J.

Darracott, P.

McGregor, M.

Brown, R.

Elliffe, A.

Scott, J.

Taylor, A.
How the Welfare State receives New Citizens from

$$
\text { Polynesia and Asia }
$$

How the Welfare State copes with Internal Migration

21-22

23-37

39-45

47-53

55-61

69-75

75-78

79-80 
DECEMBER 1988, vol.1, no.2

Serrallach, J.

Social Work and White Racism

3-8

Duffy, G.,

Back Together Again (Families and Sexual Abuse)

9-14

McDonald, D.

The Hawke Report

Taverner, $\mathrm{P}$.

Challenging Times for Social Work Education

17-19

Reports

Birthmothers

Child Sexual Abuse

20-22

APRIL 1989, vol.1, nos 3 \& 4

Baretta-Herman, A.,

Cruse, W.

New Zealand Women Social Work Managers: A Survey 4-8

Nash, M.

Women and Social Work: Five Principles for Feminist Practice, 9-12

Shirley, I.

Community Development: A Personal Viewpoint

$13-16$

Palmer, R.

The Value of Richmond Fellowship's Therapeutic

Community in Wellington

$17-19$

Briefs

Taverner, P. Supervision

20-22

Underwood, G. Am I Fun To Work With?

$22-25$

Helmondollar, R. At last - A Union for Voluntary Sector Workers

26

Beddres, L.

Report

Reunion

27

AUGUST 1989, vol.2, no.1

Bradley, J.

Social Work Today

4-7

Nuthall, J.

Players or Spectators in the New Public Health?

$8-10$

Cree, $\mathrm{M}$.

Australia's Labour Market

DECEMBER 1989, vol.2, nos 2 \& 3

Kendrick, J.

Contracting Out: A Growing Issue of Accountability in the Field of the Elderly

Pack, M.

Doing Dirty Work? Sponsors of Community Service

Daniels, K.

Accountability and Social Work

Baretta-Herman, A. Effective Social Service Staff Meetings

Briefs

What is a Social Audit?

A Plan for Social Work - Department of Social Welfare

APRIL 2013, vol. 25, no.1

Dale, $\mathrm{M}$.

Smith, P.

Appleby, J.

Phillips, D.

Kanyi, T.

Dobi, S.

Ross, A.

McBride, T.

Fuller, J.

Robb, P.
Social Work at Whakatipuria Teen Parent Unit

Whose Culture is it Anyway? Social Working Within a Rural Community

Enhancing Engagement in CAMHS

Lack of Outcome Research on New Zealand Care and Protection Family Group Conference

$35-42$

Thinking Beyond the Contract: A Journey to Collaborative Community Social Work

Through Blue: A Support Group for Women Affected

by Depression

$54-63$

An Example of a Competency Assessment Portfolio, Adapted for Publication
64-75 
JULY 2013, vol. 25, no.2

Evans, N.

Perez-y-Perez, M. Will Marley Come Home? An Exploration of the Impacts of the Canterbury Earthquakes on People's Relationships with their Companion Animals

Tudor, R.

Social Work in the Quake Zone: Supporting the Sustainable

Development of Christchurch's Eastern Communities

Cooper-Casell N. Mind the Gap: Post Earthquake Community Wellbeing?

Van Heugten, K. Supporting Human Service Workers following the Canterbury Earthquakes

Milne, V.

Marlow, J.

Lou, L.

Maher, P.

Maidment, J.

True, J.

In the Zone: Keeping Hope Alive through Shaky Times

The Canterbury Earthquakes and Refugee Communities

$58-68$

Social Work Disaster Emergency Response within a Hospital Setting

Gendered Violence in Natural Disasters:

Learning from New Orleans, Haiti and Christchurch

78-89

Kane, R.

Smith, P.

Briggs, L.

Rourk, M.

Stewardson, A.

Crump, N.

Inner City East - One Christchurch Community's Story

90-97

Personal reflections: What happens when disaster strikes

98-104

Reflections from the End of the Earth: Social Work Planning Preparation and Intervention with Evacuees on Haemodialysis Treatment following the 2011

Christchurch Earthquake

NOVEMBER, vol. 25 , no. 3

Rennie, G.

Henderson, E.,

Fry, K.

Smith, P.

Gilray, B.

Beddoe, E.

Duke, J.

O’Brien, M.

Henderson, R.

O'Donoghue, K.
Registration Ten Years On: A Perspective From a Social Work Educator

Implementing Registration within a Health Setting Registration: Ten Years on within a Non-government Organisation

Social Worker Registration: A Decade of Debate, Development and Delivery

Continuing Professional Development of Registered Social Workers in New Zealand

Social work Registration and Professionalism: Social Justice and Poverty - Fellow Travellers or Discarded Passengers?

A Former President Reflects on the Effects of Social Work Registration upon the Association: An Interview with Rose Henderson 